\title{
MAAR NET 'N SOLDAAT (III)
}

This Biography on the war experiences of the late Mr C.J.H. Griesel has been compiled by his daughter Mrs P.J. Kleynhans and is published in four parts.

It covers the period 1899-1902 and deals with his personal experiences during the Anglo-Boer War (Second War of Independence).

Die biografie oor mnr. C.J.H. Griesel, alom bekend as oom Kassie, is saamgestel deur sy dogter mev. P.J. Kleynhans, beter bekend as tannie Nellie Kleynhans, wat tans op Bothaville woon. Die wedervarings van die Tweede Vryheidsoorlog $(1899$ - 1902) word weergegee soos wat haar vader dit aan haar meegedeel het.

\section{HOOFSTUK 11}

Die twee vrouens is toe voor kommandant Mentz gebring en hy het hulle gewaarsku om onmiddellik terug te gaan en nie weer daar te kom nie. Die een vrou het haar man, wat in ons kommando was, tog te sien gekry en haar giftige doel bereik. ' $n$ Paar dae daarna het haar man en 'n maat verlof kom vra om ' $n$ kleinigheidjie te gaan doen, ek kan nie meer onthou wat dit was nie, maar dit het in elke geval heel onskuldig voorgekom. Dit was egter die laaste sien van hulle. Ek het later verneem dat hulle reguit na Heuningspruit toe is en daar wapen afgelê het.

$\mathrm{Na}$ die oorlog het ek verder verneem dat die Engelse die een kêrel in die konsentrasiekamp gebruik het om hout te kap en tente op te slaan. So iets het hy natuurlik nie verwag nie en het glo opstandig begin word. Die Engelse het hom eenvoudig laat oppak en na Indië gestuur. $\mathrm{Na}$ die oorlog het hy self aan my gesê dat hy hom liewers moes geskiet het voordat hy sy wapen gaan afgee het.

Die papbroekige gees het toe oral kop uitgesteek. Nog voor die twee van ons kommando weggedros het, het ' $n$ betroubare vriend wat van generaal De Wet se kommando gekom het, my die volgende vertel: Hulle was tussen Kroonstad en Lindley toe daar op ' $n$ dag twee kêrels aangery kom. Die generaal het dadelik vermoed dat alles nie pluis was nie, hulle gevang en by die kommando gehou. Toe het dit gebeur dat die Engelse skielik opdaag en daar moes haastig opgesaal word. Die twee is aangesê om hulle kar self in te span en baie gou ook, maar hulle was so tydsaam as wat moontlik was. Die een wou glad eers in die spruitjie gaan was, voordat hulle gaan. Dit was natuurlik duidelik dat hulle tyd probeer wen het om weer tussen die Engelse

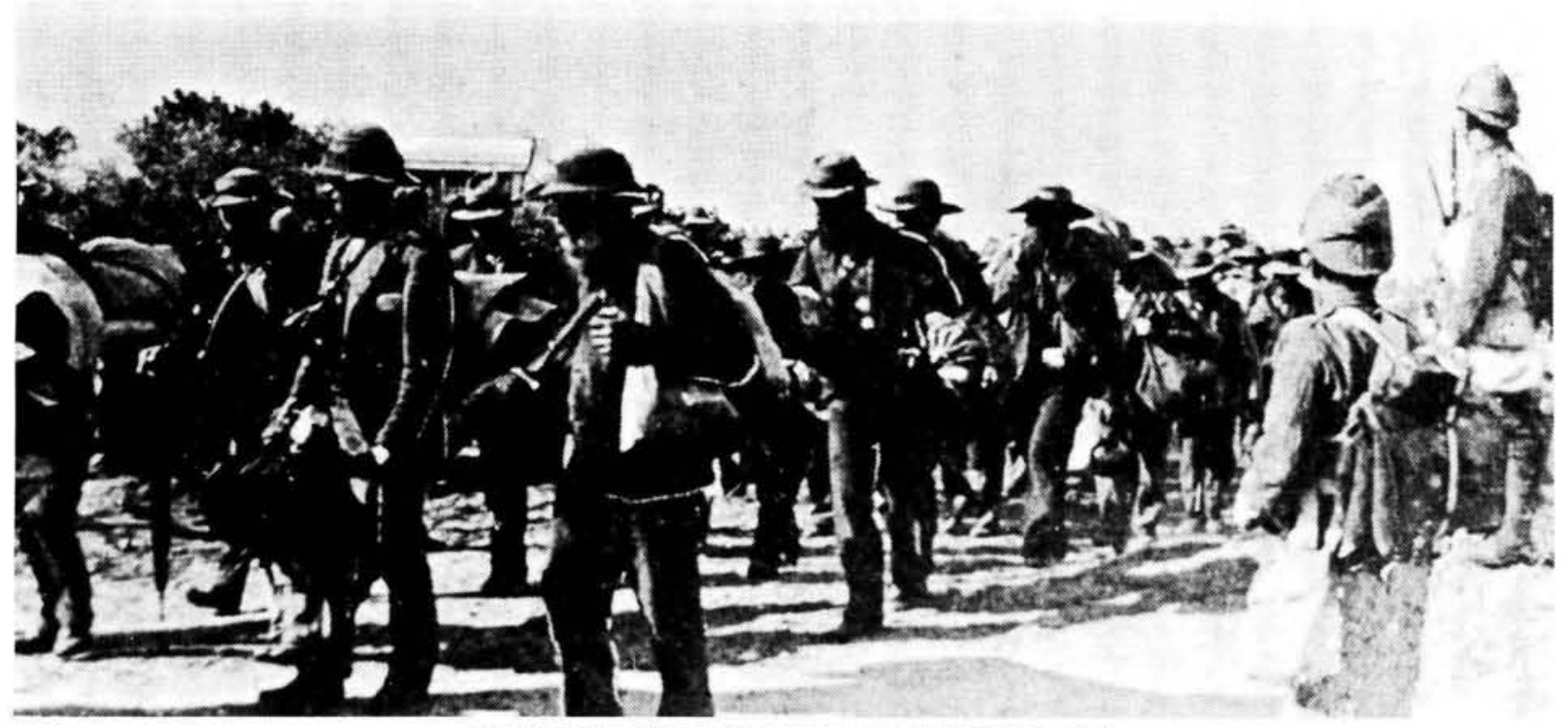

Aankoms van Boerekrysgevangenes te Simonstad.

(Foto: S.A.W. Argief - 700000337) 
te kon kom, maar hulle het nie met die generaal. rekening gehou nie. Hy het daar en dan opdrag gegee om die een wat wou gaan bad, dood te skiet. Dit is haastig gedoen en toe het die ander een geweet om gou in te span.

Dit is tog jammer dat die soort van ding onder die burgers posgevat het, want ons stelsel van klein kommandotjies was 'n ware doring in die vlees van die vyand. Hulle moes later raadop geraak het omdat hulle ons nie in die hande kon kry nie en maar gedurig verliese moes ly. Dis toe dat hulle met die blokhuise begin het. ' $n$ Reeks van die blokhuise is tussen Kroonstad en Bethlehem gebou en die hoofspoorlyn vanaf Kroonstad na die Noorde, is sterk bewaak.

Toe dit alles gereed was, het Britse magte vanaf Harrismith begin vertrek met die doel om ons in die driehoek, wat ons ramkraal genoem het, vas te keer. Met die eerste aankeer moes die Engelse aan die begin baie goeie moed gehad het, want ons het maar aangehou om terug te trek voor die magte. Hier en daar het 'n kommandotjie deurgebreek en vry gekom, maar die groot klomp van ons het voor hulle uitgetrek, reguit in die ramkraal, soos hulle moes gemeen het. Maar hulle ontnugtering was naby. Op ' $n$ sekere nag is daar halt geroep en saaklik besluit dat dit nou tyd was om uit te jaag. Op 'n gegewe oomblik het ons toe gelyk gestorm en dwarsdeur die vyand gejaag.

Die groot veldtog van die Engelse was 'n mislukking. Al die beplanning en organiseerdery was tevergeefs. Boer se kind was weer los en vry. Nou moet ek ook byvoeg dat die Britte alle lewende hawe saam met ons aangekeer het, met die gevolg dat daar na die uitjaag nie slaggoed was nie. Dit was egter nie vir ons 'n onoorkomelike moeilikheid nie. Na so 'n aankeer en uitvlug het dit gewoonlik ' $n$ paar weke geneem voordat die vyand weer gereed was vir die volgende aankeer en in die tussentyd het ons dan van die skape en beeste, wat hulle teen die treinspoor gehou het, gaan buit.

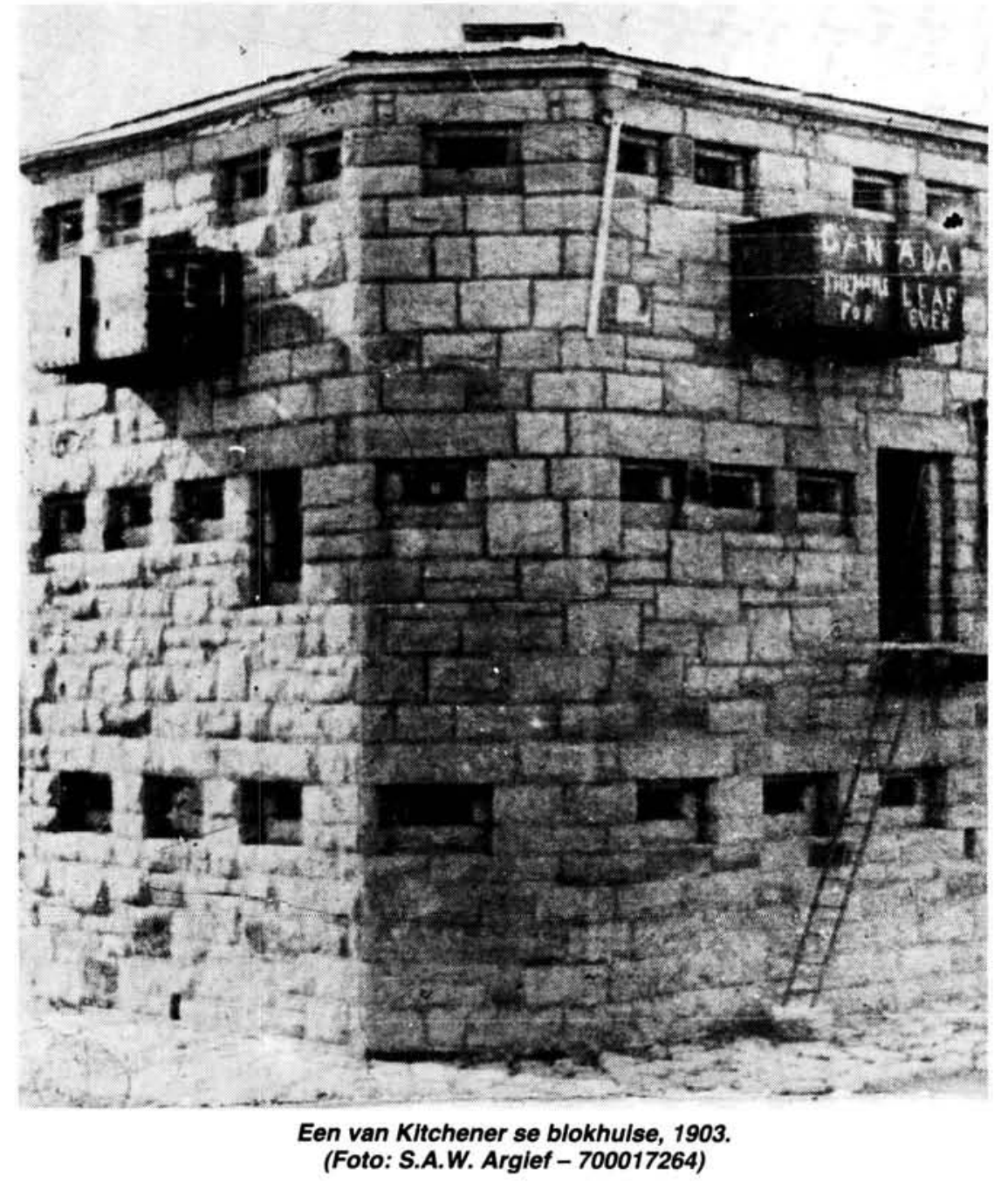


Die heel eerste beeste wat ons gaan haal het, was besmet met longsiekte, maar daarteen was 'n plan. Die eintlike rede was om te sien of ons dit kon regkry om met die vee uit te kom. Ons het die trop beeste eers goed dopgehou om seker te maak waar hulle snags slaap en toe gereed gemaak om hulle te gaan vat. In die donker het ons klompie aangery en nie te ver van die beeste nie, het die burgers hulself versteek en ek en Antonie Meyer het alleen nader gegaan.

Die beeste was in 'n groot kraal, deels van klip en deels van draad. By die hek het twee Swartes op wag gesit. Ons het tot byna by hulle gekom, toe sê Antonie: "Trap! Of ek skiet julle dood!" Dit was nie nodig om 'n enkele woord verder te praat nie. Die twee het laat vat en ons het geweet dat hulle reguit na die Engelse kamp toe hardloop, maar dit was eintlik soos ons dit beplan het. Ons wou nie dat daar 'n skoot geskiet word nie, want dit sou die vyand te gou op ons hakke bring.

Ons het die beeste baie gou uitgejaag, maar ons was skaars driehonderd treë weg, toe was die eerste vuurpyl oor ons en ook 'n bom. Van die beeste het toe begin vassteek en hoes en ons het geweet dat dit longsiekte was. Die ander burgers het toe bygekom en ons het maar aangedruk en uitgekom met die beeste.

Die volgende oggend het kommandant Mentz na my gekom en gesels oor die mooi trop beeste wat ons gebuit het. Dit was om en by die driehonderd beeste wat ons daardie nag gebuit het. Hy het ook gevra of ek gesien het dat daar longsiekte onder hulle was. Ek het hom toe gesê dat ek dit weet, maar dat ek ook 'n plan daarmee het. Ek het 'n ou oom geken wat presies geweet het hoe om beeste teen die siekte te ent en ek sou die raat gaan haal. Die probleem was net dat die ou oom feitlik teen die treinspoor gewoon het. Die beeste was vir ons van lewensbelang en ek en Jan Taljaard het in die nag weggespring. Ons moes groot versigtigheid aan die dag lê, maar het veilig deurgekom.

Die ou oom het gesê om 'n siek bees dop te hou en sodra hy dood was, moes hy op sy rug gedraai word om so koud te word. Daar moes dan 'n opening aan die galkant gemaak word en die gal moes dan versigtig uitgeskep word sodat daar nie bloed bykom nie. Dan word smal bandjies in die gal gedoop en deur die beeste se stertkwasse getrek; dit wil sê deur die vel van die kwasse. Ons het die voorskrif noukeurig nagekom en al die beeste geënt. Die ente het so kwaai gegroei dat daar van die beeste se sterte afgeval het, maar die longsiekte was ook op 'n end.

Die tweede aankeer na die ramkraal is toe uitgevoer en het op dieselfde patroon as die eerste verloop. Later toe ek in die hospitaal was, het die tommies aan my vertel dat hulle die uitjaery van ons gevrees het. Wanneer ons kom en hulle bevel kry om te storm, het hulle liewer gevlug. Ek het hulle geglo, want in so ' $n$ geval het ons eenvoudig platgejaag wat voor ons kom. Buitendien sou ons perde hulle nooit laat inhou het nie, want hulle het die ding geken. Volgens die tommies is daar met elke uitjaag van ons klomp van hulle beseer onder ons perde se pote.

In die paar weke wat ons dan vry was, moes ons ook afreken met die Swartes wat gesteel en gemoor het op die plase. Hulle het 'n ware pes geword. Na die tweede ramkraal het ek 'n rapport van kommandant Mentz gekry om met 'n klompie van my mense die Swartes te gaan voorlê. Ek het die opdrag uitgevoer en ons het stelling ingeneem op die plaas Beeskraal, naby Koppies. Die nag teen twaalfuur kry ek ' $n$ tweede rapport: "Kom uit. Weer 'n ramkraal."

Ons is toe dadelik daar weg maar toe ons by Vegkop aankom, het die meeste burgers al deurgebreek. Daar was nog 'n klompie ouerige burgers en saam met hulle was ons omtrent veertig wat in die knyp gesit het. Ons het begin rondvlug om 'n opening te soek en die skape wat ons by ons gehad het, laat staan. Naderhand het ons die beeste ook laat staan en so het die geënte beeste vir die tweede keer onder die vyand beland. Ons het toe nog 'n klompie los perde gehad wat in die sorg van ene Labuschagne en sy twee seuns was. Laasgenoemde drie en Stoffel Venter is toe met perde en al gevang.

Ons kommandotjie het toe deur Renosterrivier gevlug en toe die burgers die bosse bereik, het drie van ons, Salie Smit, Jan Taljaard en ekself, ' $n$ entjie terug gejaag teen die hoogte uit om die wêreld te verken. Die Engelse jaag toe sowat agthonderd treë regs van ons agter die kommando aan.

My perd was gedaan. Toe ons die hoogte weer afgaan, het ek aan my maats gesê dat ek nie verder kon wegkom nie, want my perd was kapot. Ons het beraadslag wat om te doen. Hulle wou my nie laat staan nie en hulle eie perde kon ook nie meer ' $n$ dubbele vrag dra nie. 
Ek het hulle toe beslis gesê om te gaan. Dis beter dat een in die slag bly as al drie. Buitendien sou ek nie daar gaan sit om gevang te word nie. Die kêrels het my traag verlaat, maar die vyand het toe reeds op ons begin skiet en hulle moes jaag om uit te kom.

Ek het my perd stadig laat aanstap na 'n laagte naby die rivier. Die Engelse het nog 'n paar skote op my geskiet, maar toe blykbaar gedink dat ek so goed as in hulle hande was en hulle meer toegespits op die kommando, wat kwaai teruggeskiet het. Die son het ondergegaan. Ek het nog altyd gehoor skiet en geweet dat my mense my ' $n$ kans wou gee om weer by hulle aan te sluit, maar my perd was eenvoudig te gedaan.

In sulke oomblikke voel mens aardig. Jou hart en jou plig is by die kommando, maar jy verkeer in totale onmag. $\mathrm{Na}$ watter kant jy jou ook al wil wend, dis net Engelse en nogmaals Engelse net waar jy kyk. In die laagte het ek by 'n kuil water gekom, hier het die gras baie ruig gegroei. Daar het ek die saal en toom afgetrek en dit in 'n sloep aan die punt van die kuil gegooi.

Die stomme perd, wat 'n uitstekende dier was, het ek met hangende kop laat staan. Met my geweer, patroonband, waterkannetjie en verkyker het ek toe gehardloop om wegkruipplek in die rivier te soek. Toe ek die wal afgaan het ek 'n taaibos gesien wat vroeër afgekap moes gewees het, want dit het in ' $n$ taamlike digte bos gegroei. Tyd om vir 'n beter plek te soek, was daar nie meer nie en ek het in die taaibos gekruip.

My geweer het ek mooi regop agter my neergesit en my waterkannetjie, wat leeg was, voor my. Ek was ook net betyds, want ek het skaars gesit toe hoor ek die voorste tommies agter my op die wal. My gedagte was dat hulle eers deur die rivier sou trek voordat hulle kamp opslaan, maar na 'n rukkie moes ek tot my ontsteltenis ontdek dat hulle daar rondom my gaan oornag.

$\mathrm{Na}$ ' $n$ rukkie het hulle téén die taaibos die wal afgekom om water te skep. As daar ooit 'n mens roerloos stil gesit het, was dit ek, want as hulle net behoorlik opgekyk het, moes hulle my gesien het. Dit was Desembermaand en die muskiete het my ongenadiglik getakel, maar ek kon nie soveel as ' $n$ vinger verroer om die goed bietjie te verjaag nie; hulle moes maar steek.

In my binneste het dit nie beter gegaan nie, want onder die waterskeppers wat so heen en weer by my verbygegaan het, was Engelse, Swartes en Afrikaners. Om hulle so met gemak onder die vyand te sien beweeg het 'n moordlus in my wakker gemaak. Het die mense dan geen gewete gehad nie? Ek was waaragtig bly toe die waterskeppery ' $n$ einde gekry het. Ek het toe geluister hoe hulle hout breek en vuurmaak, maar toe die geur van braaivleis my bereik, was dit byna onuithoubaar. Ek het die vorige dag laas iets te ete gehad en moenie praat van die dors nie. Dit is heeltemal waar dat mens eerder sonder kos kan klaarkom as sonder water.

Dit was ook ' $n$ pynlike en byna onuithoubare ding om uur na uur in presies dieselfde posisie te bly sit. Die begeerte om ' $n$ bietjie te versit moes met die uiterste inspanning onder dwang gehou word. Ek kon dit nie waag om te roer nie, want die voorste vure was sommer hier vlak by my. $\mathrm{Na}$ die oorlog het ek gehoor dat die Labuschagnies en Stoffel Venter wat vroeër die dag gevang was, net omtrent driehonderd treë van waar ek in die bos gesit het, in 'n huis bewaak is. Hulle het natuurlik ook nie kon droom dat ek sommer naby hulle in so 'n penarie was nie.

Later in die nag toe dit begin stil word en ek gereken het dat dit veilig genoeg was, het ek my geweer en patroonband mooi versteek in die bos en met my waterkannetjie afgesak na die water. Ek kon byna nie ophou drink nie, maar ek moes ook ' $n$ tydjie afknyp om opgeswelde gesig en oë met koue water nat te maak. Die muskiete het behoorlik ' $n$ feesmaal van my gesig en oë gemaak. Baie versigtig het ek toe al aan die waterkant in die rivier opbeweeg vir omtrent honderd treë en toe teen die wal uitgeklim. Ek het doodstil bly staan om alles mooi waar te neem.

Op die plek waar ek uitgeklim het, was daar baie muile, maar na 'n rukkie het ek ook agtergekom dat patrollies kort-kort inkom en uitgaan. Ek het toe geweet dat ons kommando dopgehou word met die doel om hulle die volgende oggend te gaan vang. Ek het nie daaraan getwyfel dat die kommando op die regte tyd weer sou uitjaag en skotvry wegkom nie, maar ek het ook gewonder die hoeveelste teleurstelling van die Engelse dit sou wees. Hulle vaskeerdery het ons nie veel geskeel nie en om uit te jaag, was vir ons en die perde, nie 'n groot kuns nie.

$\mathrm{Na}$ ek die kom en gaan van die patrollies goed waargeneem het, het ek my kans afgewag. Net toe ' $n$ patrollie van sewe man weer by my verby was, het ek opgespring, oor die pad gehardloop 
en tussen die muile gaan lê. Daar het ek 'n rukkie gelê en luister hoe gulsig en vergenoegd die diere vreet asof daar niks in die wêreld verkeerd was nie.

Ek het toe besluit dat dit tyd vir aanstap was. Gelukkig was ek baie goed bekend met die wêreld daar langs, en na ek 'n hele ent gestap het en geen hindernisse teengekom het nie, het ek gemeen dat ek nou vry was. Ek het die paadjie gevolg na die plaas van Wouter Weilbach en daar het ek 'n ontnugtering gehad. Ek het my vasgeloop in ' $n$ nog groter mag Engelse as die waarvan ek so pas ontsnap het. Ek moes toe halt roep en my posisie in oënskou neem.

Die Engelse laer was ' $n$ bietjie laag af en ek wis toe dat hulle brandwagte op die hoogte sou wees. Die beste plan was dus om tussen die laer en die brandwagte te probeer deurgaan. Dit sou die gevaar, om in die brandwagte vas te loop, uitskakel. So gesê, so gedaan. Ek het baie versigtig vorentoe beweeg en toe ek omtrent halfpad by die laer verby was, hoor ek die bekende fluitteken van ons burgers. Ek het dadelik doodstil gaan lê. Sou daar waarlik van my mense in die nabyheid wees? Ek was opgewonde en het met spanning geluister of die teken herhaal word, maar dit was tevergeefs; die bekende ou fluit het uit die Engelse laer gekom.

\section{HOOFSTUK 12}

Ek het weer begin aanstap en gemik vir die grootpad. Teen hierdie tyd was ek uitgeput van honger en vermoeienis, want vandat ek twee nagte tevore van Beeskraal af teruggeroep is, was daar geen rus of tyd om iets te eet nie.

Ek het langs die grootpad gehou tot by die plaas van Tys Uys en daar ontdek ek éérs 'n groot Britse mag. Dit was toe werklik soos oom Kassie dit uitgedruk het: Die wêreld het gewemel van die Engelse. Ek het dadelik weggeskram van die grootpad af en die veld gekies. Vinnig kon ek nie meer oor die weg kom nie; dit het maar strompelend gegaan en toe my voet agter ' $n$ miershoop vashaak en ek val, het ek nie weer opgestaan nie. Ek het nie bedoel om te bly lê nie, maar toe my liggaam die aarde raak, het die slaap my in 'n oomblik oorweldig.

Toe ek weer wakkerskrik was dit al helder lig en ek het dadelik opgespring om myself skaars te maak. Ek het presies geweet hoe die ramkraal bewegings verloop, en het ook geweet dat daar in die afgelope nag dinge gebeur het. Ons bur- gers het of uitgebreek of was gevang. Maar wat die toedrag van sake ook al was, een ding was seker, die Engelse sou nou weer terugtrek op die ou patroon en ek moes sorg om uit hulle pad te bly.

Nie ver van waar ek geslaap het, het ek 'n klipskeur gekry en daarin weggekruip, maar die honger het so geknaag dat ek omtrent enigiets sou waag net om ' $n$ stukkie kos in die hande te kry. Ek het toe gedink aan 'n plaas in die nabyheid waar moontlik ryp vye en appelkose kon wees en het weer begin stap. Ek het die plaas veilig bereik, maar tot my teleurstelling was die vrugte nog groen. net so hier en daar was 'n vruggie wat begin uitswel het en ek het dit maar so half groen geëet. Soos te wagte kon wees, het die halfgroen vrugte op so 'n leë maag moeilikheid gemaak. Ek het 'n ontsettende pyn op die krop van my maag gekry. Dit was naderhand so erg dat ek onder die vyelaning rondgekruip het van pyn.

Maar hoe siek en gedaan ek ook al was, ek moes daar wegkom, want die plaas sou reg in die pad van die terugtrekkende vyand wees. Ek het toe maar my maag vasgevat en aangesukkel na ' $n$ hoë bult op dieselfde plaas. Bo-op die bult was 'n paar ou kliphutte en ek het in een gekruip. Dit was omtrent ook soveel as wat ek kon doen, want ek was te siek en honger.

Ek was net ' $n$ rukkie in die hutjie of ek sien deur 'n opening dat die voorste Engelse aankom en reguit afpyl na die bult waarop ek my bevind. 'n Benoude en wanhopige gevoel het toe op my neergesak, want ek was te siek om verder te vlug. My enigste hoop was dat hulle sou wegswaai as hulle by die grootpad kom en nie besoek op die bult sou aflê nie.

Dit was toe ook so; ek het so gelê en kyk hoe hulle oor Renosterrivier trek in die rigting van Heilbron. Na die laastes verby was, het ek gereed gemaak om verder te gaan. Die pyn op die maag het effens bedaar, hoewel ek nog baie sleg gevoel het. Ek het al langs die hang van die bult geloop vir omtrent ' $n$ myl en toe weer hoërop geklim om na Vegkop se kant te kyk. As die burgers daarin geslaag het om deur te breek, sou hulle daar wees. Met my verkyker het ek die wêreld goed bespied en hier en daar ' $n$ ruiter opgemerk, maar ek kon nie vasstel of dit vriend of vyand was nie.

Op 'n ander kop daar naby, oom Andries Wessels se kop, soos ons gesê het, gewaar ek toe 'n 
klomp perde wat staan en slaap. Later het ek ook manskappe sien beweeg en gesien dat twee op hulle perde klim en reguit koersvat in my rigting. Dit het my onrustig laat voel, want ek was glad nie seker met wie ek te doen het nie en my toestand was van so ' $n$ aard dat indien nodig, ek betyds moes vlug. ' $n$ Ent daarvandaan was ' $n$ ou klipbreekgat en ek het daarheen gesukkel om na 'n wegkruipplek te soek.

Ek het gesien dat daar ' $n$ voetpad aan die kant van die gat verbygaan en toe dit naderhand duidelik word dat die ruiters juis met dié voetpad langs kom, het ek my lyf baie skraal gehou, want dit het beteken dat hulle ' $n$ paar treë van my af sou verbygaan. Ek het maar kort-kort geloer om te probeer uitmaak wie dit was en toe hulle omtrent so vierhonderd treë van my af was, het ek weer gekyk en my hart het 'n ruk gegee van blydskap. Dit was Bennie van der Merwe en Herklaas Roelofse, twee van my ou makkers.

Ek was skoon oorstelp van blydskap toe ek besef dat hulle weer eens daarin geslaag het om die vyand te ontglip en dat ek aanstons weer tussen hulle sou wees. Dit het my ook dadelik opgeval dat hier ' $n$ kans duisend was om hulle 'n poets te bak. Ek het doodstil bly lê totdat hulle regoor my was en toe opgespring en geskreeu: "Hensop!"

Die kêrels het byna van hulle perde afgeval, want dit was seker die laaste ding wat hulle op daardie tydstip verwag: die Engelse was mos klaar verby. Maar Bennie het my byna onmiddellik herken en uitgeroep: "My magtig, hier is ou Kassie!" Dit was vir hulle ongelooflik om my weer in lewende lywe te sien. Daardie ontmoeting sal ek nooit vergeet nie; ' $n$ mens se gemoed het sommer vol geskiet.

Hulle het my vertel dat daar groot onsekerheid omtrent my was. Daar was mense wat vertel het dat hulle gesien het hoe ek van die perd afgeskiet is. Ander het weer vertel dat hulle gesien het dat ek gevang is. Een ding was darem seker: hulle het nie in die minste verwag om my daar te kry nie en nog lewendig ook! Ek moes seker nie van die beste daar uitgesien het nie, want die kêrels het my bekommerd aangekyk en was baie jammer dat hulle niks byderhand gehad het om te eet nie. Ons het besuit dat ek sou aanstap na ' $n$ paar strooise wat daar naby was en hulle het net so omgespring laerplek toe om vir my ' $n$ perd te kry en vir my te laat kos maak.

Ek het die ou skepsel wat daar gebly het, baie goed geken en hy was ontsteld om te sien hoe sy basie lyk. Hy het gou vir my 'n veldstoeltjie gaan haal om op te sit en suurpap gebring om te eet. Ek wil sê dat daardie suurpap een van die smaaklikste etes was wat ek ooit geniet het. Die goeie ou skepsel het na die ete ook vir my bietjie rooktwak gebring wat ek met dankbaarheid aanvaar het, want dit was ' $n$ weeldeartikel.

So was dit in die oorlog. 'n Gewapende Swarte was 'n uiterste barbaar en ons het sy bloed gesoek, maar daar was ook die goeies en getroues soos die ou van wie ek pas vertel het; en daar was baie van hulle. Gevoed met die lekker suurpap en met 'n stopseltjie twak het ek sommer heerlik tuis gevoel daar langs die stroois met sy vriendelike mense.

Ek het nog so lekker gesit toe sien ek iemand aangejaag kom met ' $n$ handperd. Dit het so vinnig gegaan dat die saalklappe van die handperd sommer so oop gestaan het en toe hy naby genoeg was, sou ek sien dat dit Hendrik Taljaard was, die onnut! Maar waar was ek bly om hom weer te sien! Hy het ook sommer van die perd afgespring, my om die nek gegryp en gehuil van blydskap. Ek kon ook vooraf gedink het dat hy nie iemand anders sou toelaat om vir my 'n perd te bring nie.

Hoe armoedig die toestande ook al was, het Hendrik sy bes probeer om my feestelik te onthaal. Met sy koms het hy sonder die medewete van die ander burgers ' $n$ draai gemaak by ' $n$ paar vrouens wat nie gevang was nie en onder 'n paar sinkplate teen die murasie van hul afgebrande huise gewoon het. Daar het hy vir my 'n ete bestel. Dié ete het bestaan uit gekookte mielies wat in 'n koffiemeule gebreek was en 'n stukkie vleis sonder sout. Dit is afgerond met kafferkoringkoffie sonder melk of suiker. My hart het gekrimp van jammerte want die omstandighede was voorwaar treurig. Terselfdertyd was dit vir my ' $n$ gedenkwaardige maaltyd. Dit was vir my voorgesit deur my eie mense uit die goedheid van hulle harte; hulle het gegee wat hulle gehad het en ek sal dit nooit vergeet nie.

Ek wil hier net byvoeg dat sout destyds ' $n$ baie skaars artikel was. Soms was ons gelukkig om stukke sout op Engelse laerplekke op te tel, maar daar was tye wanneer ons maar daarsonder moes klaarkom. Wanneer die soutlus te kwaai geword het, het ons soms spesiaal uitgegaan om sout te soek.

Met meel het dit ook maar swaar gegaan. Van 
die burgers wat aan die ander kant van die spoorlyn was, het soms weggebreek van die kommando om meel by Witzieshoek te gaan haal en dan het ons weer 'n plan gemaak om by hulle te kom en ons deel te kry. Dit was 'n baie gewaagde onderneming om oor die spoorlyn te kom, want die Engelse het gedurende daardie tyd al hul aandag op die spoorlyn gekonsentreer. In elk geval, ons het dit reggekry en wanneer ons iets in die hande gekry het, het ons dit altyd met die vrouens op die plase gedeel.

$\mathrm{Na}$ die gasvryheid wat ons van die vroue ontvang het, is ek en Hendrik na ons laerplek toe. Daar was die ontmoeting net so aangenaam. Die burgers het 'n groot ophef gemaak toe ek, die doodgewaande die laer binnekom. Ek het die hartlike ontvangs waaragtig waardeer. Ek het sommer in staat gevoel om my plek meer as vol te staan, al was ek nog bewerig in die bene. 'n Lekker stuk vleis was klaar gebraai vir my en ons kon nie uitgesels raak nie, want ons klompie was baie geheg aan mekaar.

Hulle het my vertel dat dit maar broekskeur gegaan het, maar eindelik het die kans gekom waarvoor hulle gewag het en hulle het oudergewoonte met geweld deur die Engelse gejaag. My pakperd met my komberse het hulle ook veilig uitgebring. Ek was veral bly oor my velkombers, want die het ek spesiaal groot gemaak om die winterkoue uit te hou.

Nadat ek by my mense terug was, het ek so opgewonde gevoel dat ek lus gehad het om hulle bymekaar te roep en aktief te raak. Maar ek het myself bedink. Dit sou verstandiger wees om 'n paar dae te wag sodat ek ' $n$ bietjie kon herstel om behoorlik in staat te wees om my skoene vol te staan. Die gedagte aan my geweer daar in die taaibos het egter aan my geknaag en na 'n dag of wat het ek 'n paar kêrels gevra om saam te ry om my geweer te gaan haal.

Kassie van der Merwe, Niklaas Viljoen en nog ' $n$ burger, op wie se naam ek ongelukkig nie kan kom nie, het toe saamgegaan. Ons het reguit na die kuil gery en ek het die saal en toom nog net so gekry, soos ek dit daar gelaat het. Omtrent honderd treë daarvandaan het my arme perd gelê. Die Engelse het hom doodgeskiet en ons is toe na die rivier en ek het ook my geweer en patroonband in die taaibos gekry net soos ek dit gelaat het. Die kêrels by my was verbaas dat ek geslaag het om in dié wegkruipplek ongesiens te bly. Laat ek maar sê ek was self verbaas toe ek die spulletjie mooi bekyk. Die vuurmaakplek- kie was feitlik rondom en baie na aan die taaibos, maar ek wou geweet het of daar ' $n$ mens bestaan wat stiller as ek kon gesit het.

\section{HOOFSTUK 13}

Daarvandaan het ons vier na Beeskraal gery. Op ' $n$ hoë knop het ons Engelse spioene gewaar en die wêreld eers goed verken. Ons sien toe ook dat daar in die laagte, tussen die knop en 'n woning, vier perde loop en dié kon ons nie laat staan nie; perde het ons te nodig gehad.

Twee van ons kêrels het toe gegaan om die perde aan te keer en ek en Kassie van der Merwe het reggestaan om te skiet as die Engelse dalk moeilikheid wou maak. Dit was toe ook so. Net toe die kêrels die perde begin aankeer, het hulle begin skiet van die kop af. Ons het nie 'n besonderlike vrees vir Engelse koeëls gehad nie, want dit was tog maar meesal bo-oor en die twee manne by die perde het dus nie geskrik nie, maar die perde aangebring.

So 'n astrante optrede moes die tommies verwoed gemaak het, want hulle het die kop afgestorm en aanhoudend geskiet. Kassie en ek het toe 'n paar koeëls gevaarlik naby hulle geplant en hulle het net so omgespring en teruggejaag. Dit was vier eersteklas perde wat ons die dag gevat het. Ek het die eerste kans gekry om een uit te soek en ek het ' $n$ baie goeie perd gekry. Ek het dadelik my eie saal op sy rug gesit en met my eie geweer weer in my hande, het ek weer soos 'n volwaardige burger gevoel.

Ons is weer terug na die laerplek en kort daarna het ek opdrag van die kommandant gekry om Swartes te gaan voorlê. Ek het vyftien man geneem en omdat hierdie opdrag byna my lewe gekos het en hulle my so trou bygestaan het, sou ek graag elkeen se naam wou noem. Maar dis lank gelede en 'n paar het my ontgaan. Wie ek nog onthou, is Kassie van der Merwe, Niklaas Viljoen, Hendrik Taljaard, Josua Viljoen, Koot Cilliers, Kerneels Els, Herklaas Roelofse, Bennie van der Merwe, 'n sekere Herbst en my oom Stefaans Griesel.

Daardie nag het ek met hulle getrek tot op Jan Combrinck se plaas en die meeste daar agtergelaat om reg te staan vir moeilikheid. Ek en Josua Viljoen het gery tot op die volgende plaas. Toe die son die volgende oggend opkom, het ek twee ruiters van die spoorlyn se kant gesien aankom en teen die rooikoppies uitgaan. Ek het hulle goed met die verkyker dopgehou en gesien dat dit Swartes is. 


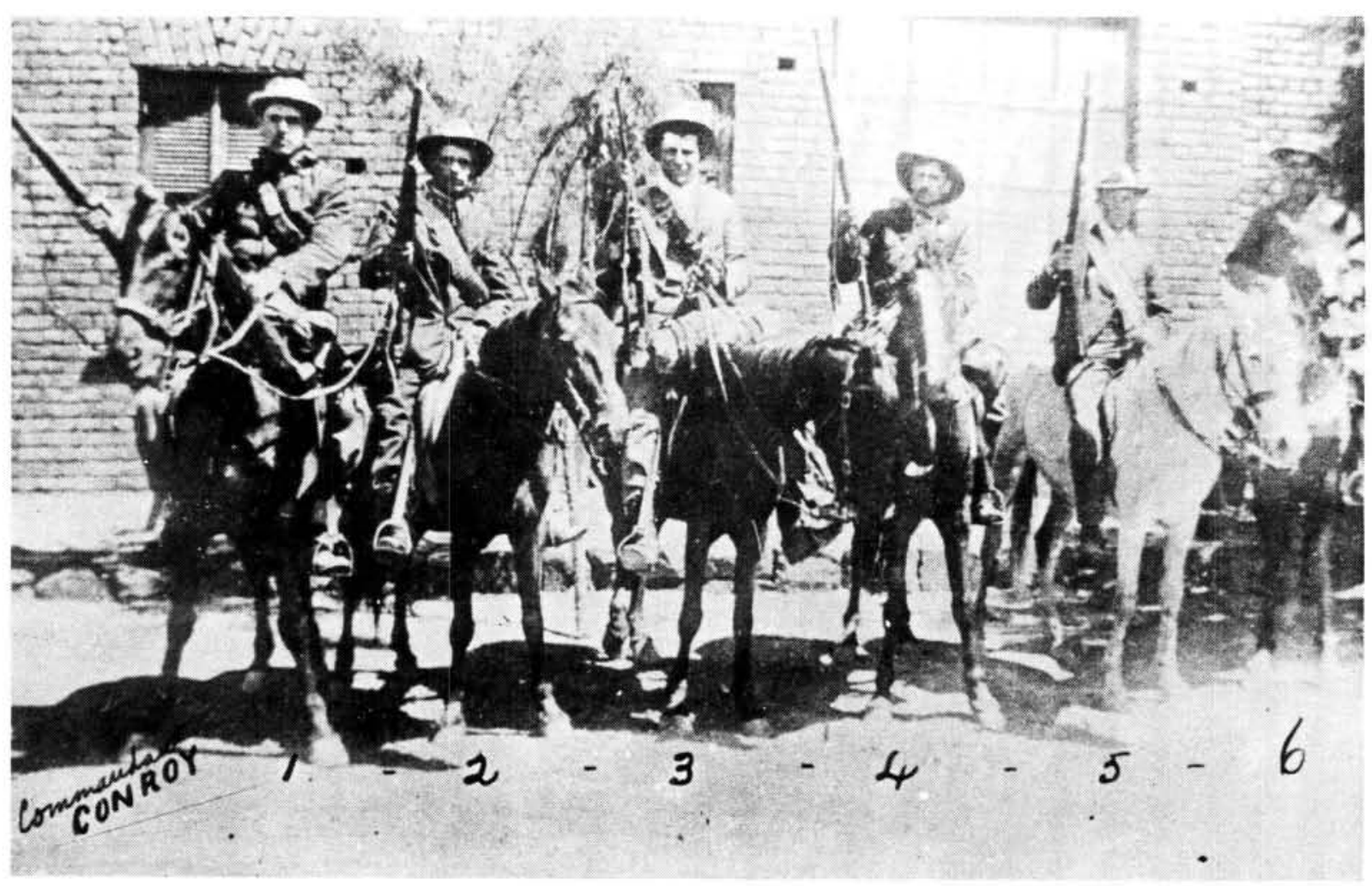

Lede van 'n Kommando.

(Foto: S.A.W. Argief - 70000001624)

Ek en Josua het besluit om ons in die spruit, Doornspruit, te versteek en te wag. Die twee het op die koppie gebly tot omtrent twaalf-uur die dag. Toe was daar 'n beweging en ons het gesien dat hulle op hulle perde klim en reguit op ons skuilplek in die spruit afstuur. Naderhand het hulle effens geswaai en bokant ons deur die spruit gegaan. Ons was reg en het net gewag dat hulle anderkant moes uitkom, sodat ons hulle kon skiet.

Indien daardie eerste skote van ons raak was, sou ek baie ellende vrygespring het. Maar soos die noodlot dit wou hê, was dit nié raak nie. Ek het al baie gewonder of ons nie te opgewonde geraak het wanneer ons met die Swartes deurmekaar geraak het nie, want ons kon tog byna voor die voet ' $n$ netjiese skoot skiet. Maar hoe dit ook al mag wees, die Swartes het onmiddellik gejaag na 'n paar murasies daar naby en het venynig teruggeskiet.

Ek het toe aan Josua gesê om daar te bly en hulle dop te hou, terwyl ek gou jaag om 'n paar manne by te kry, want dan kon die saak gouer afgehandel word. Dit sou net nie betaal om 'n lang skietery aan die gang te sit nie en dit was net wat sou gebeur het, want die twee was goed verskans. ' $n$ Uitgerekte skietery sou ons net die Engelse op die hals gehaal het. Ek het haastig op my perd gespring en net toe ek op die spruit se wal uitkom, skiet een van hulle skrams oor my perd se nek sodat die maanhare in my gesig spat. Ek was briesend kwaad, maar kon vir eers niks doen nie en het my perd die spore gegee. Ek was baie gou terug met die ander burgers, maar in die tydjie het die twee uitgejaag en toe ons op die bultjie uitkom, sien ek dat Josua hulle agternasit.

Die twee knape het ons gewaar die oomblik toe ons op die bult verskyn en het toe sommer die spruit ingejaag. Dit was ' $n$ moeilike affêre, want ons kon hulle nie te sien kry nie en ons het toe ook geweet dat hulle nie te sleg skiet nie. Hulle perde kon ons wel sien; die het hulle aan mekaar vasgemaak in die spruit.

Nou was daar ' $n$ menigte spoelslote in die spruit en ons het geweet dat hulle in een daarvan was. Dit was ook moontlik dat hulle in so 'n posisie was dat hulle elke beweging van ons kon dophou terwyl ons oop en bloot sou moes aanstap om na hulle te soek. Ons het toe eers beraadslaag. Om hulle so te laat staan was uit die kwessie en aan die ander kant kon ons ook nie te veel tyd mors nie, want die Engelse kon enige oomblik toeslaan en dan moes ons vlug want teen hulle oormag was ons nie bestand nie. 
Ek het toe op my knieë aangekruip totdat ek kon vasstel uit watter sloot hulle skiet en toe voorgestel dat ses van ons 'n wye draai maak en dan van die ander kant af na hulle toe stap met die vingers gereed op die snellers. Maar hiervoor was die burgers nie te vinde nie. Ek en my oom, Stefaans Griesel, het toe besluit om om die draai van die spruit te probeer kom. Daarvandaan sou ons ' $n$ beter kans hê om hulle onder skoot te kry.

Ons twee het toe gehardloop, salig onbewus dat die vloeke intussen van lêplek verander het, en net toe ons by die spruit se wal kom, sien ek hulle omtrent agt treë van my af. Ek het blitsvinnig vasgesteek om te skiet, maar die Swarte het my natuurlik gesien aankom en was gereed. Ek het net die rokie van die Martini-Henry gesien en gevoel asof 'n brandende stomp deur my bors gedruk word.

My oom, wat net agter my gehardloop het, is byna deur dieselfde skoot getref, maar hy het darem ' $n$ skoot ingekry en soos dit later geblyk het, was dit ook 'n raakskoot. Toe die koeël my tref het ek omgespring en nog omtrent twaalf treë gehardloop voordat ek inmekaargesak het. Die bloed het toe by my neus en mond uitgestroom.

Die skoot is by my linkerbors in en agter die blad uit en soos later in die hospitaal vasgestel is, het dit my hart net rakelings gemis. Die son het toe ondergegaan en die burgers was radeloos, want die Engelse het intussen opgedaag en die voorste skote het begin val. Kassie van der Merwe wou toe dat die Swartes tot elke prys eers van die gras af gemaak word. Ek kan nog onthou dat ek hom hoor sê het: "Hier lê ons broer en hy sal netnou dood wees; hy kan nie leef nie. Nou sê ek die Swartes moet eers dood voor ons padgee."

Gelukkig is hy oorreed en daar is besluit om liewer met my te probeer uitkom. Waar lewe is, is hoop, so het hulle geredeneer. Die pyn en brand wat ek gehad het, was so ontsettend dat ek nie belanggestel het in wat hulle besluit of gedoen het nie. Ek het 'n slag na die bloed om my gekyk en gemeen ek sou my doodbloei. Ek het nie kon dink dat ' $n$ mens soveel bloed kan verloor en nog leef nie. Die troue burgers het my toe op ' $n$ kombers gelê om my so te dra. Kassie het sy geweer gegryp en gou die twee perde in die spruit doodgeskiet. Toe het hulle my afgedra in die spruit.
Die manne moes teen die waterkant hou om die vyandelike koeëls te ontduik en dit het ook nie te vinnig gegaan nie, want ek was swaar. Sowat seshonderd treë in die spruit op, het hulle my weer teen die wal uitgedra, want dit was toe donker genoeg. Daarvandaan is ek na ' $n$ leë huisie gedra en neergelê. ' $n$ Paar van die burgers het toe haastig gaan soek of hulle nie ' $n$ kar en perde in die hande kon kry nie, want as hulle my wou uitbring, moes dit nog dieselfde nag gedoen word.

Nadat hulle weg is, het 'n paar ander kêrels wat beter bekend was daarlangs, agterna gegaan om 'n kortpad te wys as hulle 'n kar kon kry. Dit was ' $n$ pynlike wag en ek kon die oomblik nie afwag dat hulle moes terugkom nie. Wat ek verwag het, weet ek self nie, maar daar was tog niemand wat iets gehad het wat my verligting kon gee nie.

Koot Cilliers het intussen my geweer gevat en nie daaraan gedink dat die koeël waarmee ek die vuilgoed wou skiet, nog in die geweer was nie. Die skoot het onverwags afgegaan en almal 'n groot skrik besorg. Gelukkig is niemand getref nie.

So teen twaalf-uur die nag het hulle met ' $n$ kar aangekom en die kar en tuie is deur ' $n$ Swartman voorsien. Ek was toe al baie swak van die bloedverlies. My liggaam het ook koud geword en die pyn en brand het vererger. Vir my het dit gevoel dat ek liewer nie verroer wil wees nie en maar net daar wil bly lê. Vir die burgers was daar net een doel en dit was om my uit te kry. Hulle het alles in gereedheid gekry en my op die kar gesit. Ek het in die skoot van Kerneels Els gelê.

Dit was baie donker en daar was nie ' $n$ pad nie. Dit moes sommer deur die veld aan en hoe versigtig hulle ook al was, was dit vir my 'n haas ondraaglike toestand. Daar is toe ' $n$ riem voor vasgemaak en Herberts het die perde gelei om soveel stampe moontlik uit te skakel. Maar vir my was die geringste beweging ' $n$ marteling en ek sal daardie nag waaragtig nooit vergeet nie; dit was eindeloos.

Die koers was na 'n afgebrande huis waar Lettie Blignaut onder ' $n$ paar sinkplate gewoon het en met dagbreek het ons daar aangekom. Sy het gou vir my 'n lêplek gemaak. Eers is sakke op die grond gegooi en toe 'n kombers daaroor. Nadat ek neergelê was, het sy my wonde gewas en verbind so goed as wat sy onder omstandighede kon doen. 
Sy het my ook ' $n$ bietjie kafferkoringkoffie gegee met ' $n$ beskuitjie. Die koffie was gewoonlik sonder melk of suiker, maar as mens baie bloed verloor het, is jy dorstig en ek het dit gretig gedrink. Nadat Lettie soveel aandag aan my gegee het, het ek werklik gemakliker gevoel en ek was te goddank bly dat die rit met die kar agter die rug was. Ek het my ook baie gelukkig geag dat ek by Lettie uitgekom het, want al het ek saam met hulle onder sinkplate gelê, het ek tuis en versorg gevoel.

Die Engelse het toe weer met ' $n$ ramkraal begin en toe ek omtrent agt dae daar gelê het, het die voorste tommies daar aangekom. By hulle was 'n dokter en hy het na my kom kyk. Daar het naderhand offisiere ook bygekom en ek het gehoor die dokter aan een van hulle sê om my maar te laat staan; ek sou nie leef tot die volgende oggend nie.

Ek was bly toe ek dit hoor, want ek wou liewer sterf as om in hulle hande te val. Die offisiere het my toe ook laat staan en my ellende het al groter geword. Ek was baie swak en my bors het hoog geswel gestaan; tot my voete was geswel.

lets om die pyn te stil was daar nie en aan die verrotting wat in my aan die gang was, kon Lettie niks doen nie, hoewel sy my tot die uiterste van haar vermoë versorg het. Daar was nie eers 'n stukkie ordentlike kos waaruit ek krag kon put nie en ek het self gemeen dat my tydjie kort was.

Daar het toe tyding gekom dat ons burgers weer uit die ramkraal ontsnap het en ek het met verlange gedink aan die dae toe ek saam met hulle uitgejaag het en aan ons lewe in die veld. 'n Gevoel van moedeloosheid het my begin oorweldig. Miskien was dit omdat ek so baie siek was, maar ek kon net nie meer met goeie moed aan iets dink nie.

Daar het ook tyding gekom dat Kassie Griesel (my neef met dieselfde naam en van as ek) omgekom het. ' $n$ Jong burger wat by hom was met die uitjaag uit die ramkraal, het vertel dat hy en Kassie se perde albei getref is en dat hulle twee onder die perde vasgeval was. Daar het toe Swartes gekom en hy het gehoor dat Kassie soebat. Daarna het hy 'n skoot gehoor maar Kassie het nog steeds gesoebat. Toe was daar 'n tweede skoot en alles het stil geword.

Dit was natuurlik in die nag en die kêreltjie wat alles so moes aanhoor, het doodstil onder sy perd bly lê totdat die vuilgoed weg was en het toe te voet gevlug. Die volgende dag het van die burgers ondersoek ingestel en hulle het dit gekry net soos die man vertel het. Kassie het daar gelê met twee skote deur sy kop.

Hierna het die een gewonde na die ander by Lettie aangekom. Die eerste een van my was Krisjan Botha, met 'n skoot deur die voet en dit nogal 'n eienaardige geval. Hy was tuis met siekteverlof om te herstel van 'n skoot wat hy deur sy een voet gehad het. Maar nog voordat die voet heeltemal gesond was, het een van ons spioene daarlangs gery en Krisjan het besluit om saam te gaan.

Hulle het verder gery om by die rante te kom. Toe hulle bo-op was, het Krisjan se maat afgeklim. Krisjan het op sy perd bly sit omdat sy voet nog te seer was en toe het die onverwagte gebeur. Tommies het skielik by hulle uitgespring en geskree: "Hands up!" Die kêrel wat by Krisjan was het net gesê: "Verdom nie!" Op sy perd gespring en die twee het probeer uitjaag.

Die Engelse het hulle goed onder die lood gesteek en toe hulle omtrent agthonderd treë weg was, is Krisjan se perd onder hom doodgeskiet. Dit was seker maar ' $n$ verdwaalde koeël, maar die ongeluk was dat dieselfde koeël ook deur Krisjan se gesonde voet is. Sy maat was gelukkig 'n flikse kêrel en onder die skietery het hy Krisjan agter op sy perd gehelp en hulle het veilig uitgevlug.

Die tweede gewonde wat aangekom het was Piet van der Merwe en ek wonder hoeveel mense kan sê dat één koeël ses gate deur hulle geboor het, want dit is wat met Piet gebeur het. Hy was 'n vet kêrel; so vet dat sy borste byna soos ' $n$ vrou s'n uitgestaan het. Die koeël wat van die dwarste af gekom het, het toe eers deur elke bors gegaan en toe deur die arm latende ses gate. Die man se arm was af en hy het hulp nodig gehad.

Die volgende gewonde was ' $n$ seun van omtrent twaalf jaar, Nicolaas de Kock. Hy het ook 'n skoot deur die bors gehad, maar net hoër op as myne, en vir hom was ek baie jammer. Hy was met sy vader by generaal De Wet se kommando en is in die nag op die blokhuislyn tussen Kroonstad en Lindley, geskiet.

Hulle het hom ook met ' $n$ kar en perde gebring, maar langs die pad het hulle gemeen dat hy gesterf het. lemand in die kar het later agtergekom dat hy nog leef en het toe sy gesig natge- 
maak en hom versorg. Die kar waarmee hulle hom gebring het, ' $n$ twyfelaar met ' $n$ hol bak, het sy bloed opgevang.

Die laaste pasiënt wat daar aangekom het, was kommandant Cilliers, met 'n skoot deur die skouer. Lettie Blignaut het toe vyf gewondes gehad om te versorg en as mens dink onder watter omstandighede sy dit moes doen, dwing dit net bewondering af. Daar was nie ' $n$ huis nie, sy het oor geen voedsame kos beskik nie, geen pynstillende pille of enigiets anders om ons lyding te versag nie, maar sy het dit met soveel deernis gedoen dat ons versorg gevoel het.

'n Ou Swartman wat daar naby gewoon het, het gereeld vir die gewondes ' $n$ bietjie melk gebring. Dit was weer ' $n$ voorbeeld van hoe getrou baie van die Swartmense was. Die Engelse wapens en geld kon hulle nie omkoop nie.

Kommandant Cilliers se skouer en arm het hom baie las gegee en dit het naderhand so erg geword dat hy op 'n dag heeltemal deurmekaar geraak en die rante ingehardloop het. Van die burgers wat in die nabyheid was, is daarvan in kennis gestel en hulle het hom weer teruggebring. Dit het met groot moeite geskied, want wie ook al probeer het om naby hom te kom, het hy onder die klippe gesteek. Een van die kêrels het toe sy kans afgewag, hom stormgeloop en teen die grond gegooi.
Die snaaksste was dat hy met die einste seer arm wat hom tot raserny gedryf het, ook klippe gegooi het. Toe hy later weer by homself gekom het, wou hy dit nie glo nie. Hy het daarop gewys dat hy nie eers 'n vuurhoutjie met dié hand kon trek nie en tog was die burgers ooggetuie daarvan.

Later het daar 'n sekere Koornhof bygekom om Lettie met die verpleging te help. Of die man enige opleiding gehad het, weet ek nie, maar ek onthou dat hy gesê het dat die swel van my voete aan swakheid te wyte was. Hy het omtrent ' $n$ maand so by Lettie gebly en my toestand was met een woord ellendig. As ek vandag daaraan terugdink, dan weet ek nie hoe ek kon geleef het nie.

\section{HOOFSTUK 14}

Die Engelse het toe weer 'n ramkraal gevorm, maar dié keer het dit nie so voorspoedig gegaan met my klompie burgers nie. Met die uitjaag het daar, as ek reg onthou, sestien van hulle in die slag gebly en is gevang. Dit was treurige nuus. Ek het my manne geken en geweet waartoe hulle in staat was, daarom kon ek dit byna nie glo nie. Sou die Engelse ' $n$ nuwe taktiek ontwikkel het om die onverskrokkenheid van die Boer die hoof te bied?

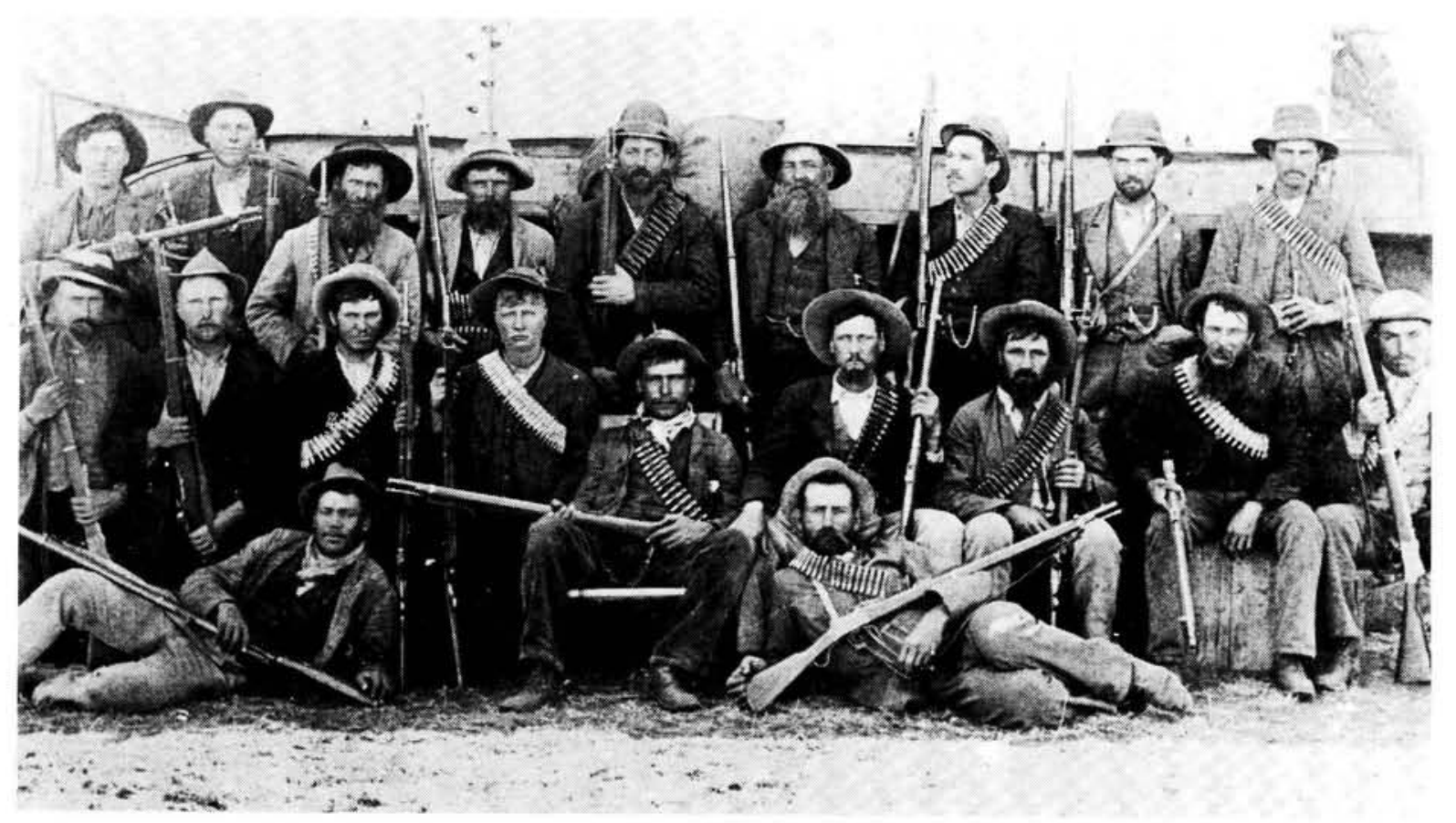

Groep Boere met gewere en bandoliere. (Foto: S.A.W. Argief - 700000169) 
Met die terugtrek van die Engelse magte het hulle toe daar aangekom om ons gewondes saam te neem en ek was geskok om te sien dat hulle die gevange burgers by hulle het. As ek nou daaraan terugdink kan ek my voorstel dat na die manskappe gevange geneem was, die Engeise hulle eers goed van naby moes beskou het om te sien hoe lyk die manne wat soveel keer soos water deur hulle vingers geglip het.

Die gevangenes is darem toegelaat om my te groet. Dit was pynlike oomblikke daardie toe ons van mekaar afskeid geneem het. Dit het gevoel of alles sommer so verkrummel en elkeen 'n vreemde oord ingaan. Die Engelse het muilwaens, wat met mielies gelaai was, by hulle gehad en ons gewondes is daarop geplaas. Toe my beurt kom en hulle my roer, het die vuilgoed by my mond en neus uitgeloop en ek het daarin gestik. Lettie het toe vir die laaste keer gekom, my bietjie skoongemaak en 'n laaste slukkie melk gegee.

Terwyl ons so gelê en wag het vir die waens om te vertrek, het my oog op die tommies daar naby geval. Ek het gesien dat een van hulle Kootjie Pretorius se perd uittrek om op te klim. Ek het die perd geken en geweet dat dit sy gewoonte was om eers ' $n$ paar geweldige spronge te gee voordat hy koers vat. Of Kootjie hom so geleer het, weet ek nie, maar dis moontlik, want hy was 'n uitstekende ruiter.

In elke geval, die tommie kon nie eers mooi bo kom nie, toe waai hy soos ' $n$ vrot vel. Die dae van lekker lag was egter verby. Ek het nie eers gekyk of hy ' $n$ tweede keer probeer nie. Die waens het toe einde ten laaste vertrek na Vredefortweg. Hulle het geen pad gehou nie, maar sommer deur die veld oor klippe en deur gate gegaan.

Ek was so neergelê dat my nek teen die sitplek van die Swarte was en hoe seer ek ook al gekry het, kon ek my nie roer nie. Al wat ek kon doen was om met die regterhand, wat ek nog op 'n manier kon gebruik, die vuilgoed voor my neus en mond weg te vat. Dit het so baie uitgeloop dat dit naderhand nat onder my was. Die pyn wat ek moes verduur met die stampery van die wa, was haas ondraaglik. Wat ek met hierdie rit uitgestaan het, was werklik onmenslik.

Later die dag het hulle bietjie uitgespan, maar aan ons is geen aandag gegee nie. Ek sou wat wou gee om net in 'n ander posisie te lê maar ek het gou gesien dat ek maar sou moes uithou, hoe ondraaglik dit ook al was. Naderhand het ek die stap van 'n perd yeiroor en toe ek my oë oopmaak sou ek sien dat dit 'n neef van my, wat 'n verraaier geword het, was. Hy het langs die wa stilgehou en my met ' $n$ bot gesig aangestaar sonder om eers te groet.

Ek was toe vreeslik dors en het om bietjie water gevra, maar sonder ' $n$ woord het hy sy perd omgetrek en weggery. Ek het in die stilte tog bly hoop dat hy hom sou ontferm en die water bring, maar hy het nie weer opgedaag nie. 'n Rukkie later het daar ' $n$ ouerige tommie by die wa gekom en toe ek na hom kyk het hy vriendelik gevra: "Hallo, old chap! How are you getting on?"

Ek het hom dadelik om water gevra. Gewilliglik het hy sy kannetjie afgehaal, dit geskud en toe gesê dat daar nie genoeg in was nie, maar dat hy vir my gaan haal. Ek was eers onrustig dat hy ook nie weer sal opdaag nie, maar hy was gou terug met die lewensbelangrike water en toe ek dit aan hom wou teruggee, het hy gesê dat ek dit by my moes hou. Hoewel daar nie meer veel in was nie, was dit tog 'n beskikking, want vir die res van die dag het daar nie weer ' $n$ kans gekom om ' $n$ bietjie water in die hande te kry nie.

Daardie aand het hulle gekamp op die plaas Swaelkrans, van Lukas Steenkamp. Die muilwaens het langs mekaar ingetrek en kommandant Cilliers het op die wa langs my gelê. Ek het na hom gekyk en aan myself gesê: "Gelukkig, hy is dood; hy kan nie meer voel nie." Maar ek was verkeerd. Hy het wel nog geleef, al het hy soos 'n lyk gelyk.

Die hele dag het ons niks gekry om te eet of te drink nie, behalwe die bietjie water wat ek by die tommie gekry het. Die aand op die kampplek het ons darem elkeen 'n bietjie brandewyn met melk gekry. Ek het so gehoop dat daar 'n beter lêplekkie vir die nag sou wees, want my liggaam kon dit net nie meer uithou om langer in dieselfde posisie te lê nie, maar hulle het ons net so op die waens laat lê. Later in die nag het ek ook nog bitter koud gekry en 'n Swarte wat dit gesien het, het 'n seiltjie oor my kom trek.

Die volgende dag het ons toe op Vredefortweg aangekom. Daar het hulle ons genadiglik van die waens afgedra en in ' $n$ tent gesit. Ons het ook ' $n$ bietjie Bovril gekry om te drink, maar dit het vir my so ' $n$ nare smaak gehad dat ek dit tot vandag toe nie kan drink nie. $\mathrm{Na}$ ons 'n rukkie daar gelê het, moes die trek weer aangaan. Ek het gevoel of ek elke oomblik kon sterf en my 
hele bolyf was nat en hard gekoek van die vuilgoed wat aanhoudend uitgeloop het.

Toe die oplaaiery weer begin, het ek uit my hart gewens dat ek oombliklik uit die helse lyding verlos moes raak, want dit het maar rof gegaan en ek het nie meer veel uithouvermoë gehad nie. Die reis moes egter sonder oponthoud voortgaan, want daar op Vredefortweg moes ons op die trein gesit word om na Kroonstad se hospitaal te gaan.

Op die stasie is ons soos mieliesakke opmekaar in 'n trok gestop, en net so laat lê. Dit was duidelik dat ons in uiters onsimpatieke hande geval het. Piet van der Merwe, die enigste een onder ons wat homself nog kon help, het ons met sy gesonde arm van mekaar af getrek, sodat die wonde nie so pynlik moes wees nie. Daardie aand het ons so min of meer om agt-uur op Kroonstad aangekom. Daar het dit darem vinniger gegaan. Ons is dadelik na die hospitaal gebring.

My bors was toe baie geswel en na die dokter my gesien het, is ek sonder versuim onder narkose geplaas en het twee snye oor die bors gekry. Later het dit vir my duidelik geword dat ek in die hande van ' $n$ baie knap dokter gekom het. Dit was dokter Orford. Hy was nog baie jonk, maar as dit nie vir sy bekwaamheid en belangstelling was nie, sou ek nie weer daar uitgekom het nie. ('n Paar jaar gelede, nie lank voor sy dood nie, het ek die voorreg gehad om hom weer te ontmoet. Daaroor word later meer vertel.)

Die snye oor die bors het in 'n mate verligting gebring. Ek het vermoed dat baie van die etter verwyder is met die operasie. Ek het nogtans geen oog toegemaak van pyn en die brand nie. Daar was toe nie so iets soos die pynstillermiddels en inspuitings van vandag nie; jy moes maar uithou en ek het nie meer veel krag oorgehad om die pyn te verduur nie. Hulle het my ook tussen gewonde tommies laat lê, weg van die paar oorlogsmakkers af met wie ek saam gely het en ek het behoorlik gevoel of ek van God en mens verlate was.

Van my huisgesinnetjie was daar niemand meer nie. My dogtertjie was toe ook al oorlede en dit was of die lewe vir my sonder sin geword het. Aan die paar sinkplate waaronder Lettie my verpleeg het, het ek met heimwee gedink. Daar was ek immers onder my eie mense en sou verkies het om daar te sterf, want ek het alle hoop op herstel laat vaar. In die nagte wat gevolg het, het ek gehoor hoe die De Kock-seuntjie in ' $n$ ander tent huil en ek het die seun bitter jammer gekry. Gelukkig het hulle lateraan besluit om ons klompie weer bymekaar te sit en toe was die kind ook meer tevrede.

'n Pasiënt wat saam met ons gelê het en wat reeds daar was toe ons aangekom het, was 'n sekere Kichner; ' $n$ jong seun van so sewentien jaar, sou ek sê. Hy het swaar gely en sy gekerm het my baie ontstel. Die tommies het my vertel dat daar van sy derms afgeskiet was en dat dit nie wou aangroei waar dit gelas was nie. Wat hy ook al eet en drink het by sy sy uitgeloop. Sy bene was kromgetrek en hy was letterlik net vel en been. Die mening was dan ook dat dit net ' $n$ kwessie van tyd was voordat hy sou sterwe.

Baie jare na die oorlog het ek egter verneem dat hy fris en gesond geword het en dat hy op Senekal woon. Ek het ook 'n portret van hom by vriende gesien en kon skaars glo dat dit die uitgeteerde seun van die hospitaal was.

Die suster wat op diens was by ons tent, was 'n beduiwelde stukkie mens. Sy was suster McCloud. Sy het 'n paar kwaai swart oë gehad en onder ons was sy bekend as Swartjie. Dit was baie duidelik dat sy vir ons geen tyd gehad het nie, maar die noodlot het dit so bewerk dat ons juis van haar afhanklik moes wees. Maklik was dit nie, want by meer as een geleenheid het mens gevoel of jy alle perke kon oorskry, maar omstandighede het ons gedwing om teen wil en dank alles te verdra.

Om 'n voorbeeld van haar haat vir ons te gee, wil ek net vertel dat sy meer as een oggend op ons, "Morning, sister" geantwoord het met: "Morning, rubbish!" Met sulke geleenthede het kommandant Cilliers baie dinge kwytgeraak. Sy het ook geen geleentheid laat verbygaan om ons ongemaklik of onrustig te laat voel nie. So het sy op ' $n$ aand vir Piet van der Merwe 'n paar pille gebring wat hy moes drink, maar Piet wou dit nie sommer sluk nie. Hy wou weet waarvoor dit was. Sy het hom toe gesê dat sy arm die volgende oggend afgesit sou word.

Piet was stom van verbasing, want sy arm was baie beter! Toe het hy homself reggeruk, die pille teruggestoot en kort en kragtig gesê: "Not a damn!" Hy het nietemin 'n onrustige nag gehad en toe dr Orford die volgende oggend sy verskyning maak, het Piet besluit om alle onsekerheid uit die weg te ruim en gevra waarom sy arm dan 
afgesit moes word. Nou was dit weer die dokter wat verbaas was en hy vra Piet waar hy aan so iets kom. Piet het geantwoord dat hy dit van suster McCloud self gehoor het.

Dokter Orford het niks daarop gesê nie, maar sy misnoeë was duidelik op sy gesig te sien. Daar is toe wel die dag aan Piet se arm gewerk, as ek reg onthou is die been van die arm geskraap, maar dit het pragtig gesond geword. ' $n$ Ding wat vir ons snaaks was, was dat die suster die aand nie haar verskyning gemaak het nie. Die volgende oggend het daar ' $n$ ander suster saam met die dokter gekom, suster Hill, en ons het geweet dat die goeie dokter ons van Swartjie verlos het.

Suster Hill was 'n liewe, simpatieke mens; net mooi die teenoorgestelde van Swartjie en dit was ' $n$ heerlike verligting om onder haar sorg te wees. Ek was die Here dankbaar vir die uitkoms, want ek was toe al so swak dat ek vir elke beweging van 'n ander afhanklik was. Die dag het aangebreek dat die dokter my kom sê het dat ek weer 'n operasie moes ondergaan. Ek het maar onseker gevoel of ek nog so 'n toer sou kon deurstaan, maar dit was 'n keuse van tussen lewe en dood. Ek het darem volle vertroue in my dokter gehad.

Die volgende oggend is daar toe 'n opening tussen my ribbes gemaak. So teen vier-uur die middag het ek bygekom en gesien dat die vuilgoed deur 'n pyp in 'n bakkie voor die kateltjie loop. Toe die naarheid en ongemak van die operasie gesak het, het ek ' $n$ werklike verligting gevoel, maar ook agtergekom dat ek glad nie meer die mens is wat ek was nie. Wanneer die tyd nader kom dat die dokter met die wond werk, het ek senuagtig geword.

Hy het gewoonlik die verbande vinnig afgeruk en ek was die vermoë kwyt om vas te byt en uit te hou. Wanneer die verbande af was, het hy gereeld gevra waarvan ek die meeste hou: "'n Lang pyn of 'n kort pyn?" 'n Paar dae na die operasie is dr Orford vir agt dae na Johannesburg en die dokter wat intussen waargeneem het, was ' $n$ baie jammerhartige man. Die pyp wat in die wond was het uitgekom en toe hy dit wou terugsit het ek seergekry. Hy het toe 'n dunner een geneem. Dieselfde proses is ' $n$ paar keer herhaal en elke keer is ' $n$ dunner pypie gebruik. Toe dr Orford terugkeer, het hy gevind dat die opening gans te klein was. Hy was baie ontevrede en voordat ek wis wat aangaan, het hy my styf om die lyf gevat en die gat met sy vinger oopgeboor. Dit was vir my ' $n$ bietjie te veel. Ek het flou geword en die skotteltjie goed wat ek in my een hand vashou, het op die vloer te lande gekom.

$\mathrm{Na}$ dit klaar was, het hy soos sy goeie geaardheid was, my om verskoning gevra omdat hy my so seer moes maak en mooi verduidelik hoe noodsaaklik dit was dat die plek oopgehou moes word. Vir 'n paar maande het ek so gelê. My gedagtewêreld was op 'n laagtepunt. Daar was niks oor om na uit te sien nie en ek het gewonder waarom ek nog leef. Ek was moeg van lyding en het verlang na die dood. Ek was naderhand baie uitgeteer en deurgelê en op my agterkop was geen hare meer nie.

Die goeie suster Hill het toe op haar eie na vere gaan soek en vir my klein sagte kussinkies gemaak vir die deurgelegde plekke. Elke dag het ek 'n kwart botteltjie Stout gekry om te drink, maar ek kon dit nie in my liggaam kry nie; dit was te sleg. Die tommies kon nie verstaan wat met my aangaan nie en het die botteltjie met begerige oë aangestaar. Toe ek dit egter aanbied vir twee en ses (halfkroon) per botteltjie, was die besigheid gevestig.

Hulle het presies geweet watter tyd van die dag ek dit kry en wanneer dit kom, het daar gereeld 'n paar reggestaan met hul halfkrone. Kommandant Cilliers het toe met my gepraat en gevra dat ek dit teen wil en dank maar moes wegsluk, want hy was seker dat dit my sou goed doen. Ek het toe ook so gemaak en het werklik beter begin eet.

Dit klink gou om te sê dat ek vir 'n paar maande so gelê het, maar vir my was dit 'n eindelose tyd. Afgesien van die verknorsing waarin ek dag en nag in die hospitaal verkeer het, was daar die groot kommer oor hoe sake met ons burgers in die veld verloop.

Die nuus wat ons daar in die hospitaaltente bereik het, was nie goed nie en ons het ook nie altyd geweet wat om te glo nie. Wanneer ek die tommies bietjie probeer pols het, het hulle altyd net vertel van soveel Boere wat doodgeskiet was en soveel wat gevange geneem was en dit het voorwaar begin lyk of alles tevergeefs was.

Intussen het die verswering in my bors voortgewoed en dokter Orford het my vir die derde keer kom sê dat hy weer gaan opereer. Hy het verduidelik dat daar fyn beentjies in my longe was en voordat dit nie verwyder was nie, sou ek nie 


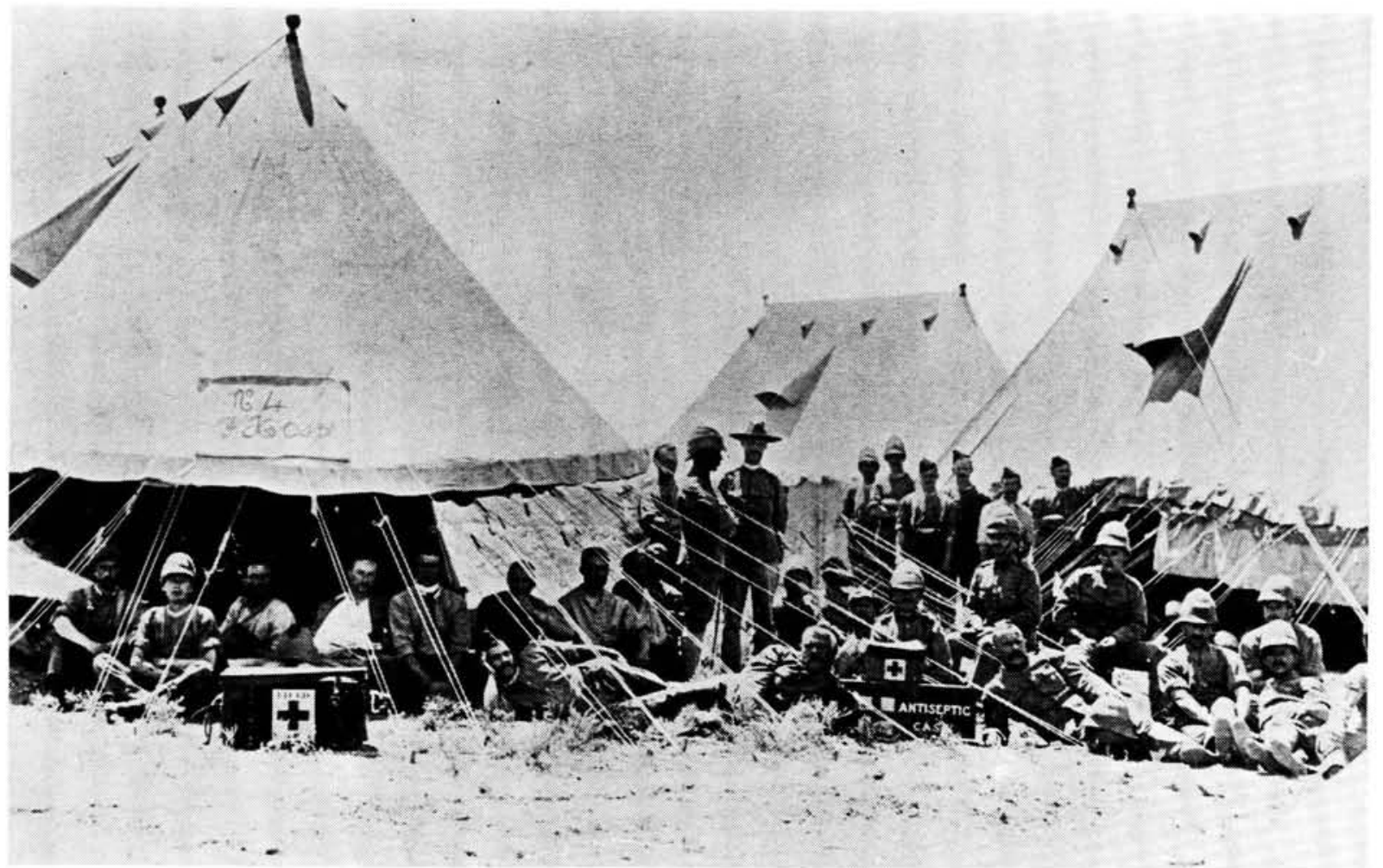

Britse veldhospitaal langs die Oranjerivier.

(Foto: S.A.W. Argief - 70000389)

herstel nie. Hoe gedaan ek toe al was, kan seker begryp word, maar ek het niks daarop gesê nie; vir my het dit nie veel saak gemaak wat verder gebeur nie. Ek was moeg van die maandelange lyding in die hospitaaltentjie. Dit was beslis iets anders as die gerieflike hospitale van vandag met al die moderne hulpmiddels.

Dan het alles ook daarop gedui dat ons volkie se saak verlore was. Toe ek nog in die veld was, moes ek al gruwelike verwoesting aanskou en hoe dit teen hierdie tyd moes gelyk het, kon ek my nie voorstel nie. Na my eie woonplek kon ek my gedagtes nie laat gaan nie. My huisgesin was uitgewis en alles wat ek besit het, was verwoes. Net die kaal verlate plaas het oorgebly.

\section{HOOFSTUK 15}

Dit was 'n groot operasie. Dele van die vierde, vyfde, sesde en sewende ribbes is verwyder om die drukking op my hart en een long te verlig. Ek het swaar gekry om weer tot verhaal te kom na hiérdie operasie, maar dit was ook die keerpunt van my ellende. Baie stadig, maar seker het beterskap begin intree.

Min of meer ' $n$ maand na hierdie operasie het die vrede gekom. Dit was ' $n$ dag so eentonig as al die ander toe suster Hill by my bed opdaag en my die tyding van die vrede gebring het. Toe ek dit hoor, kon ek nie 'n woord uitkry nie en my gemoed het volgeskiet, en suster Hill het saam met my gehuil.

$\mathrm{Ja}$, dan het daar ' $\mathrm{n}$ einde gekom aan die dood en verwoesting; ' $n$ einde aan die ongelyke stryd. Wat nou oorbly, was om te weet wie almal omgekom het en wie van die familie en vriende nog leef.

$\mathrm{Na}$ die tyding van vrede het daar groot feestelikhede begin. Engelse, lerse en Skotse blaasorkeste het om die beurt verbygemarsjeer en "God save the King" gespeel. Vir my het dit soos 'n dodemars geklink. Voor my geestesoog het 'n prent verbygegaan van verslane en verslae burgers wat in stilte terugkeer na die verlatenheid van wat eenmaal hulle gelukkige wonings was.

Die malle vreugde van die vyand was soos sout in 'n rou wond, maar daar was nou niks anders oor as aanvaarding. 'n Rukkie hierna het ek besoek ontvang van niemand anders as die vriend wat die nag onder die katel gelê het terwyl ek met sy vrou gesels het. Waarom hy gekom het weet ek nie, want hy kon my nie in die oë kyk nie. Hy was in 'n kakie-uniform geklee en was die toonbeeld van ongemak. Toe hy my vra hoe dit 
gaan, het ek hom kortaf gesê dat dit gaan soos hyself kan sien.

Hy het toe nog 'n rukkie bly staan en toe het ek gesien dat hy sy hand uitsteek na die tafeltjie wat by die kop van my bed gestaan het. Ek kon nie sien wat hy doen nie, maar kommandant Cilliers het gesien en dadelik gesê, "Kassie, moenie daardie geld vat nie, dis bloedgeld!" Of die man verligting vir sy gewete gesoek het met die geld, weet ek nie, maar langer kon hy dit nie uithou nie en is weg.

Ek was later so beter dat ek regop in die bedjie kon sit en dit was vir my ' $n$ wonderlike voorreg om na soveel maande weer orent te kan kom. Vir die eerste keer kon ek sien wat om my aangaan en dit het die eentonigheid van die lewe verlig. Vir ons klompie in daardie tent was die geringste gebeure van betekenis solank dit net afgewyk het van die doodse alledaagsheid.

Eenkeer, terwyl dr Orford in ons tent besig was, het hulle ' $n$ tommie daar ingebring wat te veel turksvye geëet het. Nou ja, die dokter was 'n besige man en hy het die tommie sommer op die naaste bedjie omgerol. G'n mens kon sy lag hou nie, want onder luide protes van die tommie het die dokter die moeilikheid sommer met die vinger verhelp en hom na buite gestuur. Hy het ook geen tyd verspil nie en ons het vir 'n slag heerlik gelag. Dr Orford het ons deurgekyk met 'n glimlag op sy gesig en net gesê: "it's hard to be a doctor."

'n Ander tommie het weer gekom met ' $n$ bloedvint aan sy nek en hy het behoorlik siek gelyk; hy kon sy kop na geen kant toe draai nie. Die dokter was weer besig, maar het ' $n$ tydjie afgeknyp en die nek bekyk. Sonder om 'n teken van sy voorneme te gee, het hy ' $n$ onverwagse en behendige druk gegee. Die pit van die bloedvint het teen die tent gespat en die tommie het soos 'n os neergeslaan. Die dokter is haastig verder en toe die tommie seker was dat hy ver genoeg was, het hy begin skel op die dokter op ' $n$ manier wat ons laat skaterlag het.

Daar was natuurlik nie elke dag sulke voorvalletjies nie en een middag het ek op die kant van my bed gesit en geluister na die stormagtige Noordewind en hoe die tente ruk en klap. Almal van ons in die tent was stil en besig met sy eie gedagtes. Vir my was dit of die onstuimige wind met sy dwarrelende stofbuie 'n duidelike uitbeelding was van die troostelose toestand van ons Volk en Vaderland.
My bed was die naaste aan die tentdeur en terwyl ek nog so sit en dink, trek 'n offisier die seilklap oop en vra of Cilliers daar is. Ek het bevestigend geantwoord en hy het kommandant Cilliers beveel om uit te kom. Hulle is daar weg sonder dat ons geweet het wat aangaan, maar ek het ontsteld gevoel. Daar is wel niks gesê nie, maar mens kon sommer aanvoel dat alles nie pluis was nie.

Toe oom Bennie, so het ons die kommandant in die privaat lewe genoem, sowat 'n uur later terugkom, het ons dadelik gesien dat hy neerslagtig was. Hy het my toe vertel van 'n Engelsman, 'n sekere Boyle, wat hy op bevel van generaal Flip Botha doodgeskiet het. Hy was glo die vierde een wat aangesê was om Boyle te skiet en wat dit toe gedoen het. Die Engelsman was glo 'n verskrikking vir die vroumense in die omtrek van Dewetsdorp en het baie kwaad gedoen. Dit was om hierdie rede dat oom Bennie begin voorkom het en hy het my gesê dat sake vir hom sleg lyk. Die man op wie se bevel hy dit gedoen het, generaal Flip Botha, was al dood en hy kon nie sien hoe hy gaan loskom sonder die getuienis van die generaal nie.

Omtrent 'n week daarna het hy weer voorgekom en ' $n$ paar dae daarna het twee polisiemanne opgedaag om hom na die tronk te neem. Oom Bennie het ons stil, sonder ' $n$ woord gegroet en ons het dit diep gevoel om hom, met sy arm nog in verbande, tussen die geregsdienaars te sien wegstap.

Jare hierna het ek hom weer ontmoet en hy het my toe vertel dat hulle hom daarvandaan na Dewetsdorp geneem het, om te wys waar Boyle begrawe was. Waar hulle snags moes slaap, is sy gesonde arm aan 'n wiel vasgemaak. Die bene van die man is toe opgegrawe en teruggebring om die saak voort te sit. Hoe die saak verloop het en hoedat hy ' $n$ paar keer tot die dood veroordeel was, is bekend.

Ons paar wat in die tent agtergebly het, kon maar nie oor die ding kom dat 'n sieke uit die tent na die tronk geneem is nie en ons het ook nie geweet wat om verder te verwag nie. As oom Bennie voor die hof gesleep word vir iets wat hy op bevel van sy-generaal gedoen het, kon hulle moontlik elkeen van ons tot verantwoording roep vir ons aandeel in die oorlog.

Die lewe het toe onsmaakliker as ooit tevore geword. Dit was vrede en om nog steeds in 'n vyandelike tent gehok te sit, was bitter. Persoon- 
lik het ek geen definitiewe planne gehad omtrent wat ek sou doen as ek die dag ontslaan word nie. Ek het so alles verloor wat myne was en die lang maande van lyding het my so afgetakel dat ek eintlik geen toekomsplanne gehad het nie. Daar was net ' $n$ begeerte om van die hospitaaltente af weg te kom; waarheen, het ek nie omgegee nie.

Met verloop van tyd het ek darem so verbeter dat ek met ' $n$ kierie en ' $n$ kruk in die tent probeer loop het. Dit was 'n eienaardige gevoel om na soveel maande weer op jou voete te staan en ek moes feitlik van vooraf weer leer om te loop. Ons het toe verneem dat dokter Orford sou weggaan en dat ' $n$ dokter Green in sy plek sou kom. Ek was al so gewoond aan dr Orford dat die berig my nog haastiger gemaak het om weg te kom en ek was Vader dank bly dat ek nie meer nodig gehad het om plat te lê nie. My vrees was egter nog nie verby nie. Ek het skielik 'n kwaai pyn agter die blad gekry, so erg dat ek dadelik bed toe is. Die wond van die vorige operasie was nog nie genees nie en ek het gemeen dat al die moeilikheid weer van vooraf begin. Ek het daar gelê en die tyd afgewag dat die dokter sy rondte sou doen. Ek het sommer baie siek gevoel en was letterlik teen die grond geslaan met die gedagte dat die ou sweerdery weer begin het.

Eindelik het die tyd vir die dokter aangebreek en die oomblik toe hy my sien het hy vasgesteek en gevra of ek siek voel. Hy het 'n naald agter my rug ingesteek en vasgestel dat dit ontsteking in my longe was. Hy moes toe weg en dokter Green, wat die rondte saam met hom gedoen het, het oorgeneem.

Daar is dadelik met warm pappe begin en toe die ontsteking eindelik gebreek was, ek weet nie meer die hoeveelste dag nie, was ek baie, baie swak. Gelukkig was dokter Green baie belangstellend; hy was tot drie keer gedurende 'n nag by my.

Soos te verstane is, het dit geruime tyd geneem voordat ek weer die kruk en kierie kon opneem en toe is ons gelukkig oorgeplaas na 'n sinkgebou, waar daar bietjie meer ruimte was sodat ek weer kon probeer loop. Ongelukkig was ons net 'n paar dae daar toe gly my kruk en met die val is ek so beseer dat ek maar weer bed toe moes gaan.

Dié toevalle het gemaak dat ek nie kon sterk word nie en daarby het ek ongelukkig en dikwels moedeloos gevoel. Die vrede was daar, maar dit het gelyk of ek gedoem was om in die hande van die vyand te bly.

lets anders wat my herstel vertraag het, was dat ek nie eintlik met hulle kos kon regkom nie. Wat ek wel geniet het, was die vla; dit het ek nooit laat teruggaan nie. lets waarna ek altyd uitgesien het, was die lekker boerekos wat tant Miem Jordaan so nou en dan vir my gebring het. Sy het in Kroonstad gewoon en het my nooit vergeet nie.

Eindelik was ek vir die soveelste keer weer met die kierie en kruk op die been en het toe mooi aangesterk. Ek kon naderhand al entjies loop, en was baie versigtig om nie weer te val nie.

Daar is verneem dat lord Kitchener per trein van die Kolonie af sou kom en toe hulle seker was van die dag van sy aankoms op Kroonstad, is ons aangesê, almal wat moontlik kon loop, om op die stasie te wees as hy arriveer. Die stasie was nou wel naby die hospitaal, maar ek was behoorlik vies vir die affêre. Daar was egter geen salf aan te smeer nie en ek het saam met die tommies ingeval.

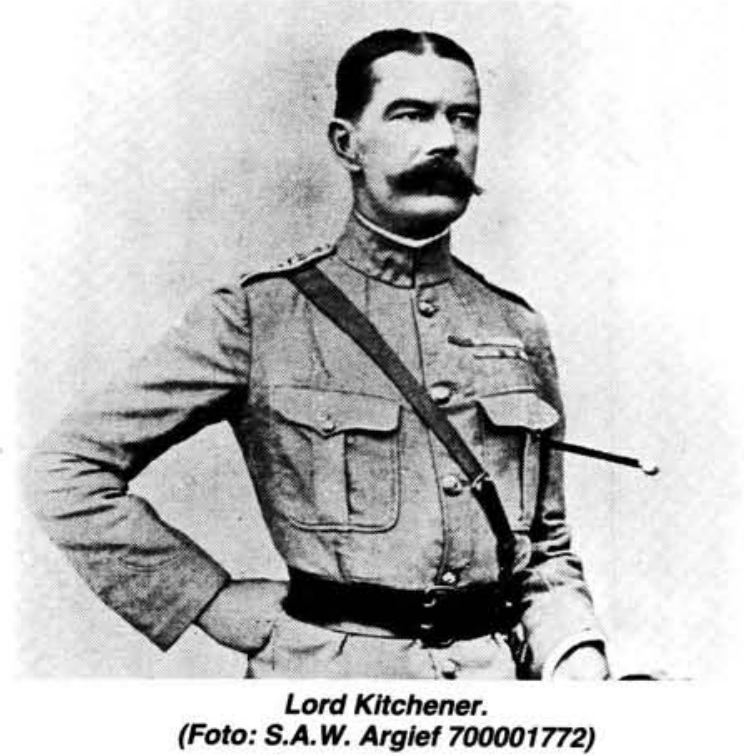

Met die blou hospitaalklere aan, het ons behoorlik soos bandiete gelyk wat op 'n ry staan. Gelukkig was dit nie nodig om lank te staan nie, want dit sou ek nie kon uithou nie. Die ry was skaars opgestel toe trek die trein in. Kitchener, met sy groot snorbaard, het toe uitgeklim. Met sy hande. in sy sye het hy ons op en af bekyk. Die tommies het gesalueer so flink hulle kon, maar daarvoor het ek nie kans gesien nie; ek het hom net vol in die gesig gekyk en my hande tuis gehou.

(Word vervolg) 


\section{KENNISGEWING/NOTICE}

Nie-amptelike ontvangers van Militaria word daaraan herinner dat hul jaarliks voor die einde van die gestelde keerdatum 30 Junie van elke jaar 'n hernuwingskennisgewing aan die Redaksie Militaria moet stuur. Versuim om dit te doen sal aanvaar word as ' $n$ aanduiding dat die geadresseerde die blad nie meer wil ontvang nie. Tussentydse kennisgewings van adresverandering onthef nie-amptelike ontvangers nie van die verpligting om hul intekening jaarliks te hernu nie.

Geliewe die nommer wat in die regterkantste boonste hoek van $u$ adresplakkertjie verskyn te kwoteer by hernuwing van u intekening. Dit is baie belangrik.
Non-official recipients of Militaria are reminded that they have to submit a notice of renewal to the Editor Militaria yearly before the set date of 30 June. Failure to do this will be regarded as an indication that the addressee no longer wishes to receive the magazine. Interim notices of change of address do not absolve non-official recipients from the requirement of renewing their subscription on a yearly basis.

Kindly quote the number appearing in the top right hand corner of your address sticker when renewing your subscription. This is most important. 